Wilfrid Laurier University

Scholars Commons @ Laurier

$6-2020$

\title{
More Than Child's Play: The Scaffolding Role of Toys, Games, and Play in Children's Literature
}

Pauline Dewan
pdewan@wlu.ca

Follow this and additional works at: https://scholars.wlu.ca/lib_pub

Part of the Library and Information Science Commons

\section{Recommended Citation}

Dewan, Pauline, "More Than Child's Play: The Scaffolding Role of Toys, Games, and Play in Children's Literature" (2020). Library Publications. 46.

https://scholars.wlu.ca/lib_pub/46

This Article is brought to you for free and open access by the Library at Scholars Commons @ Laurier. It has been accepted for inclusion in Library Publications by an authorized administrator of Scholars Commons @ Laurier. For more information, please contact scholarscommons@wlu.ca. 


\title{
More Than Child's Play:
}

\section{The Scaffolding Role of Toys, Games, and Play in Children's Literature}

\section{Shortened Title for Running Head: More than Child's Play}

\begin{abstract}
Scholars have explored the way books about toys inculcate consumer, racist, and sexist ideologies in the young, subversively controlling their attitudes and behavior. Judging from the scholarship in this area, teachers, librarians, and parents may hesitate before recommending or purchasing toy-centered stories for children. Using insights from play theorists and psychology researchers, this article argues that toy fiction can empower children by both acknowledging their marginalized status and providing models of coping, learning, and agency.
\end{abstract}

\section{Keywords}

toys; toys in fiction; play; play in fiction; games in fiction

In the 1930s, educational psychologist Lev Vygotsky felt it necessary to advocate for children's play, arguing that "it is incorrect to conceive of play as activity without purpose" (16). And in 1962, psychologist Jean Piaget observed that "play has always been considered, in traditional education, as a kind of mental waste-matter, or at least as a pseudo-activity, without functional significance, and even harmful to children, keeping them from their homework" (151). Although adults today recognize the value of play, there remains a lingering hesitation, reflected in adult characters of toy narratives. In his picture book Clown, for example, Quentin Blake depicts a stern matron holding a bundle of toys at arms-length as she heads towards a trash 
bin. Likewise, when the Boy cannot sleep without his stuffed rabbit in Margery William's The Velveteen Rabbit, Nana is dismissive of playthings: "Fancy all that fuss for a toy!" (20).

Toys and dolls—which are often miniaturized replicas of people, places, and objects— teach children about life through surrogates. Children are socialized into the world through these cultural artifacts, and scholars have explored the way adults shape children's attitudes by controlling play. Maaike Lauwaert, for example, points out that the toy industry trains children as consumers and prepares them for future sex-stereotyped roles in society. Prize-winning critical works by Robin Bernstein and Louis Kuznets examine the interconnections between children's literature and play-related material culture (Bernstein, Racial ch. 4-5). Focusing on race, Bernstein argues that children use dolls to reenact stories or resist them by refashioning the narrative (Racial ch 4, 5; “Children's"). Kuznets, who views toy literature from an eclectic but feminist-dominated theoretical perspective," finds little evidence of subversion of "elitism, racism, sexism, and androcentrism in a pervasively patriarchal culture" (8). Scholars such as Clark, Higonnet, Gonzalez, Honeyman, and Norcia examine toy literature within a cultural context, alerting us to the dissonant role of the texts. However, less attention has been paid to the way toy-themed books can empower children by helping them develop psychologically, socially, and cognitively. This article will examine stories about toys in the light of play theory and research, focusing on stories that are available to children today.

Play, as educational psychologist Susan Isaacs explains, "is indeed the child's work, and the means whereby [s/]he grows and develops" (9). It is what children do, regardless of the time period, culture, or place. "The need to play," observes Deborah Jaffé, "is so strong that, even without mass-produced toys, children will improvise, make their own, or turn a natural object or a household utensil into a plaything" (1). What is quite extraordinary is the unchanging nature of 
toys throughout time and across cultures (Fraser 18). As Jaffé points out, "Despite all the changes in social attitudes, new materials and technologies, basic toys have retained the same shapes and functions for centuries, and that core group of the ball, spinner, rattle, doll, wheeled toy, pull-along and miniature replicas remain firmly in place" (18). The very universality of play argues for its evolutionary significance and indispensable role in children's lives. Cultural theorist Johan Huizinga views play as essential, not just to children, but to civilization at large, insisting that the term Homo Ludens deserves a place alongside Homo Sapiens. Children play because it is fun; we know that they experience a feeling of well-being when participating in the activity (Singer and Singer). Because it is intrinsically motivating, play is sustained, and its benefits assured (Pellegrini). And because play is free from pressure, it is conducive to experimentation, which in turn promotes species survival (Bruner).

Like adults, children face challenges and fears. But they do not have the same knowledge, experience, and coping strategies as adults to deal with adversity. Children are more marginalized than adults and at the mercy of demands by teachers, parents, and other authority figures. Decisions are frequently made for them, ones they do not always understand or agree with. Children are often powerless, unable to express their thoughts, anxieties, and emotions in language that would help control and make sense of life. "Children think and feel deeply, in some ways more deeply than adults," writes Nina Bawden, "but they cannot express their thoughts and feelings effectively" (62). Katherine Paterson also reminds us that children experience many emotions they cannot articulate: “She hasn't the words or the experience, but she has the feelings" (224). Words, according to Virginia Hamilton, remove chaos from the world: "That's what language does. And that's what writing has always done for me. It's ordered the world and made it safe" (1021). Play functions as a child's first language, bringing into 
consciousness, emotions and thoughts that would otherwise remain subliminal. Kottman observes that "all children will express what is happening in their lives through play," a fact that enables play therapists to gain insight into their thoughts and feelings by observing themes in their play (65).

\section{Learning about the World by Proxy}

Because many toys are replicas of corresponding objects, people, and animals, children enlarge their understanding of the world by playing with these facsimile models. Since the basic desire of children who play with toys is to imitate the world around them (Fraser), they take first steps in increasing their knowledge of life through proxy play. Toys also provide information about the world when firsthand experience is not an option. Because children have less experience with life than adults and more limited access to the world at large, proxy play is especially important for them. Reading books about child characters who play with toys, or even about toy characters themselves, is a proxy activity of a proxy activity. This double degree of removal from reality eases children's introduction to the bewildering world beyond self.

In Rumer Godden's Miss Happiness and Miss Flower, a great aunt gives eight-year-old Nona a gift of two Japanese dolls. As Nona becomes interested in them, she finds out as much as possible about Japanese customs and traditions from books, her teacher, and her family. Nona learns about these traditions not just by reading or hearing about them, but by recreating them in imaginative play. Even though play cannot teach her about a foreign culture, it stimulates her curiosity and makes her aware of a way of life she never thought about before. Likewise, when Sara Crewe wants to learn about royalty in Frances Hodgson Burnett's A Little Princess, she also does so through play. "I've often thought that I should like to be a princess," she tells Becky. "I wonder what it feels like. I believe I will begin pretending I am one" (52). The knowledge she 
acquires through pretending, even if it is elementary and romanticized, helps guide her actions. As Sara says, "I pretend I am a princess, so that I can try and behave like one" (60). In Little House in the Big Woods, Pa tells Laura and Mary that he is going to take them on their first visit to a town. The girls decide to play "going to town" in anticipation of the experience (Wilder 160). Although their knowledge of town-life is nonexistent, the girls take initial steps in learning by imagining the experience. By playing with toys, Omri starts to think about Iroquois peoples in The Indian in the Cupboard, Walter about outer space in Zathura, and Madison about war in The House of Dolls (Banks; Van Allsburg; Block).

When children play with miniature replicas, they learn about the world by degrees. "To recreate the world in miniature," observes Jaffé, is a major tenet of children's play" (156). Miniatures offer in condensed form what is most essential and valued in the original (29). Just as a computer simulation provides a scaffolded introduction to a complex or dangerous experience, a toy introduces a child to a difficult, anxiety-producing, or complicated situation in a gradual way and in a protected environment. Toys as miniature replicas provide a paired down, simplified version of the original. In Satomi Ichikawa's My Little Train, a toy train takes stuffed animals on a trip around a room. They travel up "the hill of a chair" to visit a "pond" (a fish bowl), a "field" (a painting on the wall), and a "jungle" (a potted plant on the floor). Mama kangaroo awaits her child at the end of the "world tour." This journey introduces the young passengers to the wider world through a miniaturized and sheltered version of it. By playing a game called Death Kit in David Almond's Kit's Wilderness experiences what his ancestors felt when they entered dangerous coal-mines. Even though Kit's grandfather tells him, "It was very deep, Kit. Very dark. And every one of us was scared of it. As a lad I'd wake up trembling, knowing that as a Watson born in Stoneygate I'd soon be following my ancestors into the pit," 
Kit never comprehends the reality of mining life until he recreates the experience in play (19). Children, psychologists claim, not only increase their cognitive skills through "the stepping stones of play," but also "enrich their capacity to see the richness of the externally real world" (Singer and Singer 63; Winnicott, "Why Children” 144).

\section{Constructing the Future}

Vygotsky, one of most influential early play theorists, observes that children do not always understand their motives for play, but when they engage in it, they function above their chronological age. During play, children understand more than they are capable of in non-play. Play itself — rather than teachers, parents, and other guiding figures — creates a zone of proximal development which leads a child to a higher level of development. In Diana Wynne Jones's The Game, Haley Foss is raised by her grandparents in a repressive, sheltered environment. Grandma disapproves "of running and shouting and laughing and singing as well as painting outside the lines. Her ideas took in the whole world and Haley was always overflowing Grandma's edges" (16). When Grandma cannot manage Haley any longer, she sends her to live with her Irish relatives, a rambunctious lot who teach her how to play "the game." It is not until Haley does so that she gains confidence in our own abilities. The first time she plays this family game, her older cousin Troy accompanies her into the dangerous mythosphere. The game itself, not just Troy, scaffolds her learning by gradually introducing her to the dangers from which she was previously shielded. In playing the game, Haley learns about the life and discovers both her role and purpose in it. The game allows her to imagine a future in which she plays a heroic role, an activity that stimulates self-awareness and psychological development.

Like Haley, ten-year-old William, in Elizabeth Winthrop's The Castle in the Attic, practices roles and constructs his future in the zone of proximal development. When Mrs. 
Phillips_-William's caretaker from birth—announces that she is retiring, William is devastated. He cannot imagine life without her-indeed, "everything about her made him feel safe and happy" (30). He is particularly worried about his upcoming gymnastic competition, believing that he cannot manage it without the housekeeper's support. When Mrs. Phillips gives him a wooden castle as a parting gift, the knight inside it comes to life and shows William how to magically miniaturize people. The boy prevents Mrs. Phillips from leaving by transforming her into a miniature person. Although this transformation works as a short-term solution, it angers and upsets Mrs. Phillips. William then shrinks himself to toy-size and undertakes a quest in search of an amulet to restore his unhappy caregiver to regular size. In doing so, he faces the dangers of a forest alone, learns the knight's code of conduct, rescues an oppressed people, uses his gymnastic skills to fight an evil wizard, and copes with the loss of the Silver Knight. Having rehearsed his skills in play, William can now face the future confidently without Mrs. Phillips as guide and support.

A host of child characters use play to try on future roles. The boy in Chris Van Allsburg's Bad Day at Riverbend, for example, uses a coloring book to imagine what it would be like to be a brave sheriff defending his town from a dangerous threat. Hugo, in Brian Selznick's The Invention of Hugo Cabret, imagines life as a magician after he discovers a toy automaton. The boy in Mini Grey's Traction Man Is Here envisions life as a super hero when he plays with Traction Man in the kitchen sink. Volunteering for a "special mission" and diving into the “foamy waters of the Sink," Traction Man searches for the "Lost Wreck of the Sieve.” In David Wiesner's Free Fall, the boy dreams that he is a warrior in a toy castle (1988). Characters who play at future roles model for readers the satisfaction they feel as they imagine themselves in dangerous roles from the safe distance of pretend play. Cognitive psychologist Jerome Bruner 
observes that "play provides an excellent opportunity to try combinations of behavior that would, under functional pressure, never be tried" (693).

Books such as Tasha Tudor's The Dolls' Christmas, Rumer Godden's The Doll's House, and Rachel Field's Hitty: Her First Hundred Years depict girls playing with their dolls in far less exciting domestic roles. Although such books present stereotyped options for girls, not all stories about dolls do so. In The Doll People for example, Ann M. Martin and Laura Godwin create a spunky doll character who defies her parent's expectations. "I want to try things. I want to go places and see things," she tells her friend (105). Like her daring Aunt Sarah who admires famous woman adventurers, Annabelle becomes a courageous explorer. Rumer Godden's Impunity Jane and Charlotte Zolotow's William's Doll avoid sex stereotyping by depicting boys as dedicated caregivers of their dolls. Grandmother tells her son that William needs a baby doll "to hug and to cradle and take to the park so that when he's a father like you, he'll know how to take care of his baby" $(30,32)$.

Even though it "seems paradoxical to insist that children's counterfactual thoughts enlarge their engagement with reality," their imaginative rehearsal of future roles allows them to experience a variety of occupations — something they could not do in real life (Harris 190). Such simulator play environments provide scaffolded opportunities for learning. By envisioning themselves in future roles, child readers experience, not just the ideas they would think, but also the emotions they would feel in these imagined scenarios.

\section{Coping with the Past and Present}

In his seminal work, Play, Dreams and Imitation in Childhood, Piaget argues that "the child is exercising his [or her] present life far more than pre-exercising future activities" (130). The function of play, according to Piaget, is not so much preparing children for the future as 
helping them adjust to past and present realities. Play enables a child to reinterpret and reframe past experiences, especially experiences that have been challenging or not fully understood. By reliving them in play, a child brings them under her control. In Edith Nesbit's The Magic City, ten-year-old Philip discovers that the sister who raised him is engaged to be married. Although Helen reassures him that she will continue to care for him, Philip is still upset. "It won't be just the two of us any more," he tells her (5). When Helen leaves for her honeymoon, Philip is left alone with a new step-sister and her domineering nurse. An imaginative boy, he copes by creating a miniature city out of toys and household items. When he magically enters this city, he meets fantasy versions of real-world characters. Reimagining the nurse as the evil Pretenderette, Philip gains control over his life. After defeating the Pretenderette in the toy city, he is able to move from victim to victor in real life.

When a child reenacts an experience, she makes sense of it. She is able to accept a difficult or unpleasant situation by transposing it symbolically and incorporating it into her understanding (Piaget). In Selznick's The Invention of Hugo Cabret, Hugo's work on a toy automaton helps him come to terms with the death of his father. As he fixes the broken clockwork figure that originally wrote notes with a pen, Hugo begins to view it as a substitute father that will guide him: "The more he worked on the automaton, the more he came to believe something that he knew was completely crazy. Hugo felt sure that the note was going to answer all his questions and tell him what to do now that he was alone" (132). Although the message that the automaton writes does not offer the paternal advice that Hugo hoped for, it does indirectly lead him to a father figure, who in turn helps him cope with his loss. Vygotsky points out that although play is the "illusory realization of unrealizable desires," it is more than just 
wish fulfillment (7-8). As Selznick demonstrates, pretend play can satisfy a child's deep need for acceptance of a loss.

The clockwork father-and-son mice in Russell Hoban's The Mouse and His Child are joined to each other and, when wound up, dance in a circle. As the mouse child sits in a toyshop awaiting to be bought, he tells the other toys, "I don't want to go out in the world" (8). Despite his fear of leaving the protected toyshop, he is sold, and then broken in an accident. Although the toy is repaired, the mice can no longer dance in a circle: "The father, his legs somewhat bent, lurched straight ahead with a rolling stride, pushing the child backward before him" (16). The dependence of the mice on other creatures particularly bothers the mouse child: "Maybe we shan't always be helpless, Papa. . . Maybe we'll be self-winding someday" (96). The mouse child's quest for independence is a long and difficult one. He becomes completely severed from his father when a hawk drops the toy. The first time the mouse child stands by himself, he feels “a little giddy without his father's hands supporting him” (173). In The Mouse and His Child, the young mouse begins with the initial support of his father, takes halting, backward steps as the journey becomes more difficult, and proceeds with unsure steps on his own. His life models the scaffolded journey from childhood to maturity, from powerlessness to autonomy. At the end of the pair's travels, the mouse father observes, "We aren't toys anymore. . . Toys are to be played with, and we aren't" (176). Child readers undergo the mouse child's journey imaginatively, assimilating the toy's emerging insights into their lives. Although toys can suggest, as Kuznets observes, "the relatively powerless relationship of human beings to known and unseen forces" (2), the mouse's ability to withstand such forces empowers child readers.

Powerlessness is also a initial theme in Diana Wynne Jones's Homeward Bounders. Twelve-year old Jamie discovers a mysterious triangular castle that houses "Them”-cloaked 
figures playing intently with machines. They tell Jamie that he is a "discard" with no further use in "play" (26). They banish him to the "Bounds," a strange threshold area between worlds. The only way Jamie can enter play again is if he succeeds in returning home. Henceforth he is a pawn in Their game, repeatedly leaving worlds whenever one of Them finishes a game move. They appear to win the game by playing a cruel joke on Jamie: when he finally arrives home, it is a hundred years too late and everyone he knows is dead. But Jamie takes back agency by finding meaning and purpose in his never-ending wandering. He know that as long as he moves between worlds, he will be able to keep Them out. Piaget observes that imaginative play allows children to accept difficult situations by dissociating them from unpleasant contexts, as Jamie has managed to do. The Capitol in Suzanne Collins's The Hunger Games, the other mother in Neil Gaiman's Coraline, and the Nome King in L. Frank Baum's $O z m a$ of $O z$ also try to control children through games. Children in each of these books reverse power relations by outwitting adult opponents in dangerous competitions for survival.

Play functions as an alternative, transitional zone for children. Freed from the constraints of reality, they can imagine options to their present circumstances (Harris). In Chris Van Allsburg's Zathura: A Space Adventure, Danny accidently breaks his older brother's walkietalkie, greatly annoying him. After the boys find a space game in a park, they bring it home and enter the magical game world. When the older brother starts to disappear into the galaxy, he imagines how he would feel without Danny and realizes how much he loves him. Returning to the real world, Walter experiences a new appreciation of his younger brother. Similarly, in Aaron Becker's wordless picture book, Journey, a girl feels lonely and neglected when her mother, father, and sister are too busy to play with her. Alone in her room, she spies a crayon on the floor and draws a fantasy world that she magically enters. Although the dejected girl invents a world 
where she is greeted enthusiastically by others, she does not just engage in wish fulfillment. She draws her own solutions as she encounters problems. When she returns to the real world, the girl uses this proactive strategy to make friends with a like-minded boy holding a crayon.

Imagining alternatives in play frees a child to try out different self-representations or identities (Birch). In Rumer Godden's The Fairy Doll, the youngest child in a family of four is continually teased by older siblings, a situation that erodes her self-confidence. Elizabeth believes that the fairy doll on top of the family Christmas tree seems to understand her plight. When, for example, her older sister Christabel calls her "silly," Elizabeth notices that "a hard small box of sweets fell off the tree and hit Christabel on the head. The fairy doll looked straight in front of her, but the wand stirred gently, very gently, in her hand" (34). After Elizabeth drops a crystal basket, Great-Grandmother gives the distraught girl the fairy doll to help and support her. When Elizabeth asks "How can I take care of her?" Mother replies, "She is to take care of you" (46). And from that moment on, Elizabeth imagines herself as smarter and more capable. When she is asked difficult questions in class, she hears a fairy-like "ting," and immediately knows the right answer. Elizabeth is particularly upset at not being able to ride a bicycle, but when she ties the fairy doll to the handlebars, she finds the courage to do so. The doll allows Elizabeth to try on a braver, more confident personality which in turn puts an end to her siblings' teasing. By the next Christmas, Elizabeth no longer needs the fairy doll's help.

Like Elizabeth, Charlotte in Rumer Godden's The Doll's House, is timid and unassertive. Although it is out of character for her to speak up for herself or voice opinions, she does both on behalf of her dolls $(30-31,33)$. Playing with them and imagining their lives makes Charlotte aware of their helpless position. The empathy that their plight awakens in Charlotte, and the parallels that she notices between their dependency and her own, embolden her to be more 
assertive. After a china doll usurps the dollhouse and evicts dolls from it, it is Charlotte who advocates for the displaced dolls and finds a solution to their problem.

When characters confront present difficulties or painful pasts in toy literature, play advances learning by acting as a temporary support. Characters, and by extension the children who read about them, are able to experience different perspectives, try on new identities, reframe events, rehearse alternatives, and imagine solutions in the protected, simulator environment of play.

\section{Managing Anxiety and Fear}

Play can also help children manage their fears and anxieties. Pediatrician and psychoanalyst D. W. Winnicott explains that a child "plays to master ideas and impulses that lead to anxiety if they are not in control" ("Why Children" 144). Winnicott is best known for his work on toys and comfort items that young children use as transitional objects. He observes that babies and toddlers frequently become attached to a blanker, stuffed animal, or doll—-some item that "becomes vitally important to the infant for use at the time of going to sleep, and is a defence against anxiety" ("Transitional Objects" 4). Arguing that such objects symbolize the mother, and in so doing, facilitate adaptation to the world outside the self, Winnicott claims that transitional toys are essential to child development. As a first "not-me possession," and an “intermediary area of existence between a baby's inability and his [or her] growing ability to recognize and accept reality," a threshold toy helps infants transition from self to the not-me world ("Transitional Objects" 1, 3).

Trixie, the toddler in Mo Willems's Knuffle Bunny, is deeply attached to her stuffed bunny. When she visits the Laundromat with her father, she brings Knuffle Bunny with her. The toy is accidently tossed in the washing machine and left behind. Realizing her loss on the way 
home, Trixie tries to make her father aware of the problem. Her explanation- - "aggle flaggle klabble"-is clearly not understood by her father. "That's right," he responds, "We're going home." Not having the words to communicate her problem, she becomes increasingly agitated: "Trixie bawled. She went boneless. She did everything she could to show how unhappy she was." The transitional object plays such a crucial role in Trixie's life that existence without it is inconceivable to her. In Knuffle Bunny Too, Trixie takes the bunny to school for show and tell. Her animal is identical to classmate Sonia's and the girls take each other's bunnies home by mistake. When Trixie realizes the mix-up, she is so upset that her father must visit Sonia's parents in the middle of the night to exchange animals. In Knuffle Bunny Free, a slightly older Trixie leaves the bunny on a plane and is forced to manage without it. When Trixie rediscovers Knuffle Bunny on the flight home, she gives it away to a crying infant. Now Trixie is "big enough" to do without her bunny. Although Knuffle Bunny was absolutely essential as a scaffolding object, Trixie learns to internalize the support that it provided. As Winnicott observes, over time transitional toys lose their significance for the child ("Transitional Objects").

Unlike Trixie in Knuffle Bunny Free, Franklin in Paulette Bourgeois's Harriet and Franklin is not ready to give up his stuffed dog, Sam. When Franklin uses Sam to comfort his baby sister Harriet, she likes the dog so much that she wants to keep it. His mother tells Franklin that he should allow Harriet to sleep with the dog one night, but "Franklin didn't like that one bit." He hides Sam in a cupboard so that Harriet will not find the dog. Eventually the boy lets Harriet play with Sam from time to time, "but Franklin always made sure that Sam was back in his room by bedtime" (2001). Separated from their parents and susceptible to imagined fears, young children can find bedtime an occasion of high anxiety. Transitional toys, as Winnicott observes, play an essential role at such times: "Patterns set in infancy may persist into childhood, 
so that the original soft object continues to be necessary at bed-time or at time of loneliness or when a depressed mood threatens ("Transitional Objects" 4). The slightly older Oskar in Tomi Ungerer's Otto: The Autobiography of a Teddy Bear relies on a stuffed animal to allay his fears. When his friend, David, is taken away to a concentration camp, Oskar finds comfort in the bear at bedtime: "It was just the two of us. We missed David. At bedtime we would talk about him and remember all the good times we had together." And when the war-time bombing occurs, Oskar takes the teddy bear to the shelter and holds him tight. Even though Oskar is older, the teddy bear provides the comfort, companionship, and support he needs during a time of crisis.

Children are less likely than adults to directly face their fears and concerns. They are more apt to "cast issues in terms of an imagined scenario, rather than to literally mull over what troubles them (Clark 283). Jeremy in Peter McCarty's Jeremy Draws a Monster had "his very own room. He never left. He never went outside." The illustration accompanying the text depicts the young boy looking out his window at a group of children playing ball. Jeremy then draws a monster which magically springs to life. The monster demands: "Draw me a toaster. ... I like toast. Draw me a record player. It's too quiet around here! Draw me a checkerboard. I want to play checkers. Draw me a comfortable chair." The monster even takes over the boy's bed. When Jeremy creates the monster, he draws the same " 3 " on its shirt that is on his own. He casts the monster in his own image, projecting his fears onto an imagined scenario. Jeremy imagines what he might be like if he continues to avoid making friends. He then makes a decision: "The next morning, Jeremy drew a bus ticket and a suitcase" for the monster. When the monster leaves and the neighborhood children ask Jeremy if he wants to play ball, he is ready to accept the invitation. Play allows Jeremy to "symbolically anticipate the consequences of an action" (Piaget 134). 
Child psychologist, Bruno Bettelheim, maintains that play is "the child's conscious and unconscious inner world; if we want to understand his [or her] inner world and help him [or her] with it, we must learn to walk this road." Acting as a zone of proximal development, play allows a child to express "what [s/]he would be hard pressed to put into words" (Bettelheim). For preschool children, the world of reading and writing can seem like a secret code that they will never master. In A. A. Milne's Winnie-the-Pooh books, Christopher Robin projects his anxieties about becoming literate onto the toy animals. Pooh tells Owl, "My spelling is Wobbly. It's good spelling but it Wobbles, and the letters get in the wrong places" (Winnie 81). Owl's negligible reading skills are greatly admired because the other animals can barely read at all. When Pooh asks Owl to write "Happy Birthday" on a jar, Owl asks "a little anxiously" if Pooh can read. Then Owl writes, "HIPY PAPY BTHUTHDTH THUTHDA BTHUTHDY” (Winnie 82). After Christopher Robin gives Pooh a pencil case, Eeyore says dismissively, “This writing business. Pencils and what-not. Over-rated, if you ask me. Silly stuff. Nothing in it” (Winnie 159). But such bravado conceals his real feelings. Later he tells Piglet that an "A" means "Learning, it means Education, it means all the things that you and Pooh haven't got." (The House 88).

In Chris Van Allsburg's Jumanji, Judy and Peter manage their fears about growing up by imagining worst-case scenarios during a magical board game. With each roll of the dice, new disasters occur. Judy and Peter face such horrors as a lion, python, and monkeys visiting their house. In the illustrations, the patterns on the wallpaper, the fabric of the furniture, and the mother's dress all resemble the pattern on the python, suggesting links between the adult world and danger. The oddly-angled, surreal illustration of parents' looming over the children also highlights the disquieting nature of the grown-up realm. Furthermore, the two household clocks remind the children of the relentless, onward progression of time. In the game, players advance 
on the board in a specified way: "The path started in the deepest jungle and ended up in Jumanji, a city of golden buildings and towers." The route of the game from jungle to city-from primitive existence to a civilized one - is the path towards adulthood. Imagining their anxieties helps Judy and Peter vanquish them.

Lewis Carroll's Alice also faces fears of growing up by imaging game scenarios come to life - a card game in Alice's Adventures in Wonderland and a chess game in Through the Looking Glass. Through the eyes of seven-year-old Alice, the world of adults appears frightening and confusing, governed by a set of capricious conventions and customs. The Queen of Hearts's system of justice seems especially absurd and illogical: “The Queen had only one way of settling all difficulties, great or small. 'Off with his head!' she said without even looking around" (Alice's 68). The concluding trial with its logic of "sentence first - verdict afterwards" (Alice's 96) epitomizes the arbitrariness of the justice system. The conventions of language appear equally capricious. "When I use a word," says Humpty Dumpty in Through the Looking Glass, "it means just what I choose it to mean - neither more nor less." (163). Once Alice confronts her fears of growing up, these fears diminish. After the Queen of Hearts threatens to cut off her head, Alice replies, "Who cares for you? .. . You're nothing but a pack of cards!" (Alice's 97). The Queen then turns back into an inanimate chess piece. And at the end of Through the Looking Glass, Alice shakes the Red Queen chess piece until it dissolves into a kitten (204). Alice's Adventures in Wonderland ends with a vision of Alice as a grown woman. Her journey through fantasy lands helps pave the way for this transition to adulthood.

\section{Channeling Aggression and Anger}

Children use toys to manage not only their fears and anxieties, but also their aggression and anger. Peter K. Smith reminds us that adults' interest in play is not the same as children's 
and that adults generally control and channel play towards educational goals ("Social” 187;

Children 181). Although children use dolls as confidants, soulmates, and imaginary dependents, they also play with them in ways that adults may not as readily acknowledge. Adults, as Lois R. Kuznets observes, focus unduly on the child/doll relationship as a pro-maternal one but children can and do subvert this role (96). In Holly Black's Doll Bones, Alice's favourite doll is a G. I. Joe figure named Lady Jaye: "She was loud and wild, almost nothing like Alice, who chafed under the thumb of her overprotective grandmother, but did it quietly" (2). By projecting her aggression onto Lady Jaye, Alice vents emotions that she cannot do at home. Neil Gaiman's Coraline is another passive-aggressive character who channels her emotions into imaginative play. After moving houses, Coraline feels neglected by her busy parents. They have little time to devote to her, and take no heed of her food and clothing preferences. When Coraline unlatches a door that opens to a mirror-image flat of her own, she meets a couple who introduce themselves as her "other mother" and "other father" (28). Although they look like her parents, their eyes are large black buttons. These doll-like creatures devote all their attention to Coraline, filling her room with enchanting toys, and cooking her favorite meals. But as Coraline gets to know these life-sized dolls, she discovers Gothic-like features she initially overlooked: “The other mother's wet-looking black hair drifted around her head, like the tentacles of a creature in the deep ocean" (59). Opening the door to the other world, Coraline unlocks a psychological portal to her suppressed anger, and works through complicated emotions about her parents through a proxy relationship with doll-like replicas.

In Frances Hodgson Burnett's A Little Princess, Sara is overwhelmed with emotions that she redirects towards into her doll, Emily. Mistreated by authority figures at school, and forced to endure inhumane living conditions, Sara explodes with "heartbroken rage." Knocking her doll 
off its chair, she bursts out sobbing: "You are nothing but a doll! . . Nothing but a doll— doll— doll! You care for nothing. You are stuffed with sawdust. You never had a heart" (124). Once her passion expends itself, Sara detects a look of sympathy in Emily's eyes. Tom Thumb and Hunca Munca in Beatrix Potter's The Tale of Two Bad Mice take out their frustrations on a dollhouse. When Tom Thumb discovers that the food in the dollhouse is artificial, "he put the ham in the middle of the floor, and hit it with the tongs and with the shovel—bang, bang, smash, smash!” In fact, "there was no end to the rage and disappointment of Tom Thumb and Hunca Munca. They broke up the pudding, the lobsters, the pears and the oranges" $(29,30)$. When their anger subsides, they pay for the damages and clean up the mess.

In Francesca Lia Block's House of Dolls, Madison reacts to parental neglect and the uncertainty of war by punishing her dolls and sending some of them off to battle. She also hides the baby doll from its mother and takes away all of dolls' beautiful dresses. Madison's grandmother tries to atone by spending extra time with her granddaughter. She tells Madison that during her own childhood, her dollhouse compensated for living through war and losing her mother; it was her "very own world where nothing could go wrong" (42-43). Play acts as a transitional zone for painful emotions, one which allows children to release pent-up feelings and explore the consequences of their actions. When child characters express their aggression and anger in play, they learn from these experiences and return to the non-play world wiser.

\section{Rehearsing Social Skills}

Research has shown a positive correlation between pretend play and social understanding (Lillard 12-13). When children engage in play, they are able to improve their social skills in a simulator environment. Angeline S. Lillard, in "Playing with a Theory of Mind," explains that while "pretending to be a firefighter, one both carries out the behaviors that a firefighter carries 
out and sees the world through the eyes of a firefighter: one hears the fire engine's roar, feels the heat of the fire, thinks about how to rescue the burning man, and so on" (15). Children, in effect, think and feel like the person they are imagining. In doing so, they develop what psychologists call "theory of mind" - the ability to understand other's unobservable mental states. This understanding allows children to infer what others are thinking and feeling, which in turn increases their social competence (Dockett). Since children begin life focused on the self (Piaget), theory of mind competence is an especially important skill to develop. When engaged in pretend play, "children are likely to encounter views and ideas that contrast with their own perspective and to seek to resolve this conflict by constructing new understanding" (Dockett 115). What is especially extraordinary about fictional stories is that, although the situations are unreal, the emotions of the imaginer are not (Oatley). Children learn about others by actually experiencing what characters feel, think, and believe. As Lillard and Kavanaugh point out, when children pretend, they simulate others mental states and in doing so understand them.

In Anthony Browne's Gorilla, Hannah views her father as a distant, preoccupied parent: "He didn't have time for anything." What Hannah really wants is for her father to take her to the zoo to see gorillas. When he gives her a toy gorilla for her birthday, Hannah dreams that it comes to life. The life-size toy gorilla puts on her father's hat and coat which are "a perfect fit." Browne further emphasizes the connection between the gorilla and the father by drawing the same wall behind each of them in separate illustrations. When Hannah looks at the gorillas in the zoo, she realizes that they are sad, a discovery that makes her reframe her earlier ideas about her father's perceived disinterest in her. It is not until Hannah enters this simulator fantasy environment that she realizes her father is trapped in circumstances beyond his control, a situation that makes him unhappy. 
In Rumer Godden's Little Plum, Belinda discovers that her neighbor Gem owns a Japanese doll that she never plays with. Belinda sends Gem mean-spirited notes that further provoke an already strained relationship. It is not until the girls play together and imagine themselves as their courteous Japanese dolls that they learn to get along. The novel ends with the girls making the dolls bow to each other at their respective windows (145). Stories such as Gorilla and Little Plum depict a positive correlation between pretend play and social understanding. Research has also shown a positive correlation between stories and social understand as readers mentally simulate characters' actions (Mar et al.). Because readers of toy narratives simulate characters who in turn simulate reality through play, they may in fact reap increased social benefits.

Play has its own boundaries. It often occurs in a spatially separated zone: a nursery, a playground, an attic, a tree fort, a dollhouse. It is an interlude in daily life and distinct from it (Huizinga). Children are freed from the constraints of the everyday world in play; ordinary laws and customs have no force. This bounded area is also a liminal zone, a threshold area between the self and the world, and between levels of development. In play, children can act out anxieties "at one remove" in a supportive and safe environment (Smith, Children 208). It is an experimental and therapeutic zone where children learn about the world, prepare for future roles, reframe ideas, make sense of experience, reimagine power relations, cope with loss and adversity, rehearse roles and behaviors, try out alternatives, manage fears and anxieties, channel aggression and anger, and learn empathy.

When parents take away children's toys, as in Laura Ingalls Wilder's On the Banks of Plum Creek, and Holly Black's Doll Bones, the results are damaging. Laura is unable to manage her fears about her absent father and Zachary cannot cope with the reentry of his father into his 
life. Growing up has never been easy for children. Bewildered by their emotions, they do not always have the skills or the words to manage and articulate and them effectively. As children move through each stage of development, they face a new set of challenges and do so in a world that does not always provide the support that they need to thrive. Small, powerless, and lacking in experience, they are often marginalized. Toys, like children, are tiny, dependent, and helpless; not surprisingly stories about them resonate with young readers. Feeling like pawns in an adult game, children are attracted to stories that acknowledge their sense of dependency, and depict protagonists who challenge the power balance. Toys are a child's medium, and the stories about them address key concerns of childhood: growing up, developing autonomy and agency, managing fears and anxieties, and coping with adversity. Toy stories model behaviors and strategies that children can incorporate into their lives. 


\section{Works Cited}

Almond, David. Kit's Wilderness. 1999. Dell Laurel-Leaf, 2000.

Banks, Lynne Reid. "The Indian in the Cupboard." The Indian Trilogy: Indian in the Cupboard; Return of the Indian; Secret of the Indian. London: Collins, 1999, pp. 7-167.

Baum, L. Frank. Ozma of Oz. 1907. Dover, 1985.

Bawden, Nina. "The Imprisoned Child." The Thorny Paradise: Writers on Writing for Children, edited by Edward Blishen, Penguin Books, 1975, pp. 62-64.

Becker, Aaron. Journey. Candlewick Press, 2013.

Bernstein, Robin. “Children's Books, Dolls, and the Performance of Race; Or, the Possibility of Children's Literature.” PMLA, vol. 126, no. 1, 2011, pp. 160-169, doi:10.1632/pmla.2011.126.1.160.

Bernstein, Robin. Racial Innocence: Performing American Childhood from Slavery to Civil Rights. New York University Press, 2011.

Bettelheim, Bruno. "The Importance of Play." The Atlantic, Mar. 1987, www.theatlantic.com/magazine/archive/1987/03/the-importance-of-play/305129/

Birch, Marian. "In the Land of the Counterpane: Travels in the Realm of Play." The Psychoanalytic Study of the Child, vol. 52, 1997, pp. 57-74.

Black, Holly. Doll Bones. Simon \& Schuster, 2013.

Blake, Quentin. Clown. 1995. Red Fox, 1998.

Block, Francesca Lia. House of Dolls. HarperCollins, 2010.

Bourgeois, Paulette. Franklin and Harriet. Kids Can Press, 2001.

Browne, Anthony. Gorilla. 1983. Candlewick Press, 2002. 
Bruner, Jerome S. "Nature and Uses of Immaturity." American Psychologist, vol. 27, no. 8, 1972, pp. 687-708, doi:10.1037/h0033144.

Burnett, Frances Hodgson. A Little Princess. 1905. Harper Trophy, 1963.

Carroll, Lewis. “Alice's Adventures in Wonderland.” Alice in Wonderland. 1965. W. W. Norton, 1971, pp. 7-99.

---. “Through the Looking Glass.” Alice in Wonderland. 1872. W. W. Norton, 1971, pp. 103209.

Clark, Beverly Lyon, and Margaret R. Higonnet. Girls, Boys, Books, Toys: Gender in Children's Literature and Culture. Johns Hopkins University Press, 1999.

Clark, Cindy Dell. “Therapeutic Advantages of Play.” Play and Development: Evolutionary, Sociocultural, and Functional Perspectives, edited by Artin Goncu and Suzanne Gaskins. Lawrence Erlbaum Associates, 2007, pp. 275-293.

Collins, Suzanne. The Hunger Games. Scholastic, 2008.

Dockett, Sue. "Constructing Understandings through Play in the Early Years.” International Journal of Early Years Education, vol. 6, no. 1, 1998, pp. 105-116, doi:10.1080/0966976980060109.

Field, Rachel. Hitty: Her First Hundred Years. 1929. Aladdin, 1998.

Fraser, Antonia. A History of Toys. Delacorte Press, 1966.

Gaiman, Neil. Coraline. HarperCollins, 2002.

Godden, Rumer. “Impunity Jane.” 1955. Four Dolls: Impunity Jane; The Fairy Doll; The Story of Holly and Ivy; Candy Floss. Macmillan Children's Books, 1983, pp. 6-28.

---. The Dolls' House. 1948. Penguin, 1976. 
---. "The Fairy Doll." 1956. Four Dolls: Impunity Jane; The Fairy Doll; The Story of Holly and Ivy; Candy Floss. Macmillan Children's Books, 1983, pp. 32-65.

---. Little Plum. 1963. Macmillan Children's Books, 2008.

---. Miss Happiness and Miss Flower. 1961. Macmillan Children's Books, 2008.

Gonzalez, Eugenia. “'I Sometimes Think She Is a Spy on All My Actions': Dolls, Girls, and Disciplinary Surveillance in the Nineteenth-Century Doll Tale." Children's Literature, vol. 39, 2011, pp. 33-57, doi:10.1353/chl.2011.0010.

Grey, Mini. Traction Man Is Here! Knopf, 2005.

Hoban, Russell. The Mouse and His Child. 1967. Arthur A. Levine Books, 2001.

Honeyman, Susan. "Manufactured Agency and the Playthings Who Dream It for Us." Children's Literature Association Quarterly, vol. 31, no. 2, 2006, pp. 109-131, doi:10.1353/chq.2006.0038.

Huizinga, Johan. Homo Ludens: A Study of the Play-Element in Culture. Beacon Press, 1970. Ichikawa, Satomi. My Little Train. Philomel Books, 2010.

Isaacs, Susan. The Nursery Years. Routledge \& Kegan Paul, 1929.

Jones, Diana Wynne. The Game. HarperCollins Children's Books, 2007.

---. The Homeward Bounders. 1981. HarperCollins Children's Books, 2000.

Kottman, Terry. "Adlerian Play Therapy.” Foundations of Play Therapy, edited by Charles E. Schaefer, John Wiley \& Sons, 2003, pp. 55-75.

Kuznets, Lois R. When Toys Come Alive: Narratives of Animation, Metamorphosis, and Development. Yale University Press, 1994.

Lauwaert, Maaike. The Place of Play: Toys and Digital Culture. Amsterdam University Press, 2009. 
Lillard, Angeline S. "Playing with a Theory of Mind." Multiple Perspectives on Play in Early Childhood Education, edited by Olivia N. Saracho and Bernard Spodek, State University of New York Press, 1998, pp. 11-33.

Lillard, Angeline S., and Robert D. Kavanaugh. "The Contribution of Symbolic Skills to the Development of an Explicit Theory of Mind." Child Development, vol. 85, no. 4, 2014, pp. 1535-1551, doi:10.1111/cdev.12227.

Mar, Raymond A., Jennifer L. Tackett, and Chris Moore. "Exposure to Media and Theory-ofMind Development in Preschoolers." Cognitive Development, vol. 25, no. 1, 2010, pp. 6978, doi:10.1016/j.cogdev.2009.11.002.

Martin, Ann M., and Laura Godwin. The Doll People. Hyperion Paperbacks for Children, 2000.

McCarty, Peter. Jeremy Draws a Monster. Henry Holt, 2009.

Milne, A. A. Winnie-the-Pooh. 1926. Dell Publishing, 1981.

---. The House at Pooh Corner. 1928. McClelland and Stewart, 1988.

Nesbit, Edith. The Magic City. 1910. Books of Wonder, 1996.

Norcia, Megan A. “Playing Empire: Children’s Parlor Games, Home Theatricals, and Improvisational Play.” Children's Literature Association Quarterly, 29, vol. 4, 2005, pp. 294-314, doi:10.1353/chq.0.1704.

Oatley, Keith. "Why Fiction May Be Twice as True as Fact: Fiction as Cognitive and Emotional Simulation.” Review of General Psychology, vol. 3, no. 2, 1999, pp. 101-117, doi:10.1037/1089-2680.3.2.101.

Paterson, Katherine. A Sense of Wonder: On Reading and Writing Books for Children. Plume, 1995.

Pellegrini, Anthony D. The Role of Play in Human Development. Oxford University Press, 2009. 
Piaget, Jean. Play, Dreams and Imitation in Childhood, translated by C. Gattegno and F. M. Hodgson. Norton, 1962.

Potter, Beatrix. The Tale of Two Bad Mice. 1904. Frederick Warne, 1987.

Selznick, Brian. The Invention of Hugo Cabret. Scholastic, 2007.

Singer, Dorothy G., and Jerome L. Singer. The House of Make-Believe: Children's Play and the Developing Imagination. Harvard University Press, 1990.

Smith, Peter K. Children and Play: Understanding Children's Worlds. Wiley-Blackwell, 2009.

---. "Social and Pretend Play in Children." The Nature of Play: Great Apes and Humans. Guilford Press, 2005, pp. 173-209.

Tudor, Tasha. The Dolls' Christmas. Simon \& Schuster Books for Young Readers, 1999. Ungerer, Tomi. Otto: The Autobiography of a Teddy Bear. 1999. Phaidon Press, 2010.

Van Allsburg, Chris. Zathura: A Space Adventure. Houghton Mifflin, 2002.

---. Jumanji. Houghton Mifflin Harcourt, 1984.

---. Bad Day at Riverbend. Houghton Mifflin, 1995.

Vygotsky, L. S. "Play and Its Role in the Mental Development of the Child." Soviet Psychology, vol. 5, no. 3, 1967, pp. 6-18.

Wiesner, David. Free Fall. HarperCollins, 1988.

Wilder, Laura Ingalls. On the Banks of Plum Creek. 1937. New York: Scholastic, 1953.

---. Little House in the Big Woods. 1932. Scholastic, 1960.

Willems, Mo. Knuffle Bunny Too: A Case of Mistaken Identity. Hyperion Books for Children, 2007.

---. Knuffle Bunny Free: An Unexpected Diversion. Hyperion Books for Children, 2010.

---. Knuffle Bunny: A Cautionary Tale. Hyperion Books for Children, 2004. 
Williams, Margery. The Velveteen Rabbit. 1922. Avalon Camelot, 1975.

Winnicott, D. W. "Why Children Play." The Child, the Family, and the Outside World. Penguin, 1964, pp. 143-147.

---. "Transitional Objects and Transitional Phenomena.” Playing and Reality. Basic Books, 1971, pp. $1-25$.

Winthrop, Elizabeth. The Castle in the Attic. Yearling, 1985.

Zolotow, Charlotte. William's Doll. HarperCollins, 1972. 